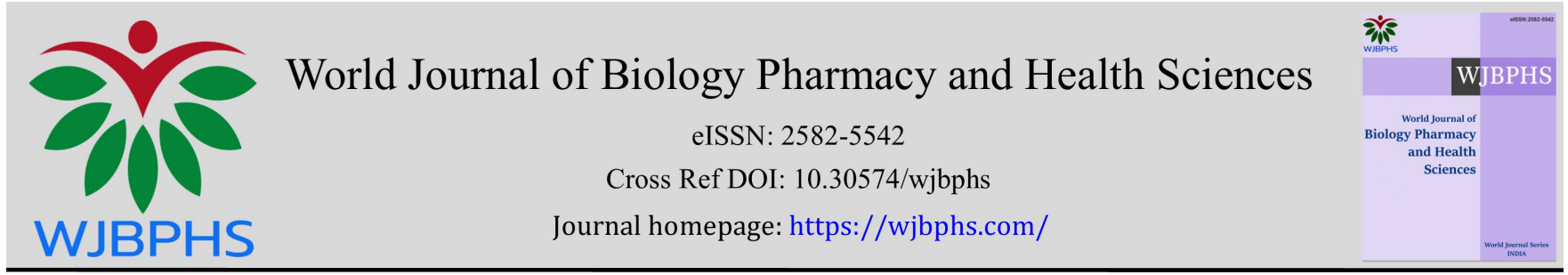

(RESEARCH ARTICLE)

\title{
In vitro cytotoxic activity of Phyllanthus amarus Schum. \& Thonn.
}

\author{
S. S. Sravanthi Pammi ${ }^{1}{ }^{*}$ and Archana Giri ${ }^{2 *}$ \\ ${ }^{1}$ Department of Botany, SVRK (M) GDC, Nidadavole, W.G.Dt., Andhra Pradesh, India. \\ ${ }^{2}$ Centre for Biotechnology, Institute of Science and Technology, Jawaharlal Nehru Technological University Hyderabad, \\ Kukatpally, Hyderabad, India.
}

World Journal of Biology Pharmacy and Health Sciences, 2021, 06(02), 034-042

Publication history: Received on 07 April 2021; revised on 10 May 2021; accepted on 12 May 2021

Article DOI: https://doi.org/10.30574/wjbphs.2021.6.2.0050

\begin{abstract}
Some bioactive compounds from plants are excellent sources of anticancer drugs. These natural phytochemicals are used in active research for cancer prevention and treatment. In our present study invitro anticancer activity was evaluated using dimethylformamide leaf extract of Phyllanthus amarus as its GC-MS analysis revealed many active principles which exhibited good antimicrobial and antioxidant properties. There were reports that anti-proliferative activity is always coupled with antioxidant activity. Anti-cancer activity of the $P$. amarus leaf extract was tested against HCT 15 and T47D cell lines and inhibitory effect on HCT 15 cell line was found to be greater than T47D cell line. With the increasing concentration of extract, the percentage of viability of cell lines was found to be decreased for both the cell lines. The anticancer activity of leaf extract of $P$. amarus is comparable to positive control drug doxorubicin. NHexadecanoic acid, lignans and polyphenol compounds in leaf extract may be responsible for the anticancer activity. These phytochemicals block cancer cell propagation by controlling cancer stem cells and can influence all the stages of cancer development effectively.
\end{abstract}

Keywords: Anticancer; Phyllanthus amarus; Medicinal plants; GC-MS; Cell lines; MTT assay

\section{Introduction}

Cancer is a serious disease caused by invasive growth of cells which tend to proliferate rapidly causing malignancies in body. Cancer cells are formed as a result of imbalance in body metabolism and destroy healthy cells of our body [1]. Cancer cells overlook the signals that normal cells take; thereby disturbing the process of programmed cell death (apoptosis). After cardiovascular disease, cancer is the leading cause of death [2] as it is related with complex mechanisms both at cellular and molecular level. Natural sources such as plants, micro-organisms and marineorganisms serve about $60 \%$ of the total anti-cancer agents [3]. Medicinal herbs exhibit anti-cancer activity because of their excellent anti-oxidant and immunomodulatory properties. Phytochemical rich diet lessens cancer risk by $20 \%$. These phytochemicals are generally natural plant derived secondary metabolites. Many challenges were faced during cancer treatment as patients undergo various types of therapies such as radiation, chemotherapy etc. In low and middle income countries (LMIC), over 20 million new cancer cases are expected annually as early as 2025[4]. Anti-cancer agents avoid or repress the growth of cancer. Plant derived compounds are gaining insight for exploiting novel pathways in cancer therapy. Plant based drugs have fewer side effects and research in plants is in continuous progress for isolating the active principles for curing various types of cancers in an effective way. Medicinal plants such as Podophyllum peltatum, Taxus brevifolia, Camptotheca acuminate, Cephalotaxus harringtonia, Catharanthus roseus etc. have been reviewed and compounds such asbetulinic acid, combrestatin and silvesterol were found to be responsible for

\footnotetext{
*Corresponding author: Archana Gir; E-mail: archanagiriin@jntuh.ac.in

Centre for Biotechnology, Institute of Science and Technology, Jawaharlal Nehru Technological University Hyderabad, Kukatpally, Hyderabad, India.
} 
anticancer activity [5]. Lignan compounds present in plants proved to play an important role in reducing risk of many cancers such as breast cancer, uterus cancer, ovarian cancers and other estrogen-related cancers [6].

P. amarus is a well-known medicinal herb belonging to family Euphorbiaceae. It is commonly known as Bhui amla and contains many active constituents which cure wide range of diseases. Alkaloids, terpenoids and other secondary metabolite compounds of plant are found to exhibit anti-cancer properties [7]. Lignan compounds such as phyllanthin, hypophyllanthin, nirtetralin, phyltetralin have been identified from extracts of $P$. amarus [8]. This plant contains an array of flavonoids such as quercetin, rutin, kaempferol, astragalin and quercitrin [9]. Tannin precursors such as Gallic acid, ellagic acid, simple tannins such as 1,6-digalloylglupyranose, 4-0-galloylquinic acid and complex tannins such as geraniin are also present in this plant [8]. Plant parts of Phyllanthus amarus were studied using different solvents for their metabolic fingerprinting studies [9] [10], antimicrobial activity [11] [12] and anti-oxidant activity [13] [14]. Gallic acid and quercetin inhibited cell cycle in G1 phase by inactivating cdc25A phosphorylation thereby inducing apoptosis in tumor cells. This is done by activating caspase activity and reducing cyclin D production [15] [16]. Phytochemical investigation revealed the presence of lignan and polyphenol compounds [17] [12]. The presence of gallic acid, gereniin, quercetin and rutin in P. amarus which exhibit anticancer properties were reported [18]. Plant derived bioactive compounds exert anticancer effects by different mode of action such as interferons induced cell death, cell death by DNA damage, autophagy induction by activation of tyrosine kinase and proteosome inhibitors[19]. Induction of programmed cell death is by use of glucocorticoid hormones and disconnection of cellular metabolism by limiting tumor cell growth. Other mechanisms include triggering apoptosis by inducing mutations in cancer cells, interfering with DNA replication by use of alkylating agents, cross linking in DNA strands by use of heavy metals, blocking of nucleic acid synthesis in cell cycle by use of antimetabolite compounds, DNA fragmentation by using mixture of glycopeptides, preventing reunion of DNA double helix during replication by stabilizing the DNA tomoisomerase II complex, preventing DNA replication by Topoisomerase inhibitors and inhibiting mitotic spindle formation by blocking tubulin synthesis [20]. Phyllanthus species were also reported to arrest cell cycle at different phases. The mechanism of action is due to interference of protein synthesis and DNA synthesis machinery. The property of uncontrolled proliferation is lost when cells cycle is arrested [21]. P. amarus was found to treat breast cancer by diminishing the potential of mitochondrial membrane, increasing reactive oxygen species intracellularly, upregulation of caspase -3 expression and down-regulation of Bcl-2 expression [18]. Four species of Phyllanthus viz. P. amarus, P.niruri, P.urinaria and P.watsonii were found to exhibit antiangiogenic effect by inhibiting capillary tube formation and anti-metastatic effect by decreasing the ability of cancer cell invasion and migration [22]. Hepatocarcinoma was treated using Phyllanthus urinaria by inducing the production of TNF by inhibiting the expression of antiapoptotic genes and secondary tumour development [23]. GC-MS analysis of dimethylformamide leaf extract revealed the presence of a compound N-Hexadecanoic acid that is responsible for anticancer activity. Our study reports the effect of dimethylformamide extract of $P$. amarus leaf on cancer cell lines (HCT 15 and T47D).

\section{Material and methods}

\subsection{Anti-cancer activity of Dimethyl formamide leaf extracts of $P$. amarus}

The cytotoxic effect of Dimethyl formamide leaf extract was tested against Human colorectal adeno carcinoma cancer cell line (HCT 15) and Human breast cancer cell line (T47D). Dulbecco's Minimal Essential Medium (DMEM) was used for cell culture studies.

\subsection{Cancer cell line development and maintenance}

The Human colorectal adeno carcinoma (HCT 15) and Human breast cancer (T47D) cell lines were obtained from the National Center for Cell Sciences (NCCS), Pune (Table 1). HCT 15 and T47D cancer cell lines were maintained in Dulbecco's Modified Essential Medium (DMEM) supplemented with $4.5 \mathrm{~g} / \mathrm{l}$ glucose, 2mM L-glutamine and 5\% fetal bovine serum (FBS) at $37^{\circ} \mathrm{C}$ in $5 \% \mathrm{CO}_{2}$ incubator (Thermo scientific, USA). Cells from exponentially growing culture were used for experimental purpose. The cancer cell lines were maintained successfully in required laboratory conditions and used for further studies i.e., Trypan blue staining and MTT assay. 
World Journal of Biology Pharmacy and Health Sciences, 2021, 06(02), 034-042

Table 1. Nature of cancer cell lines used for evaluating anti-cancerous activity of Phyllanthus amarus

\begin{tabular}{|c|c|c|c|c|c|}
\hline Cell line & Morphology & Origin & Species & Growth mode & Supplier \\
\hline HCT15 & Epithelial & Colon & Human & Adherent & NCCS, Pune \\
\hline T47D & Epithelial & Breast & Human & Adherent & NCCS, Pune \\
\hline
\end{tabular}

\subsection{Cell viability assay using Trypan blue dye}

Trypan Blue is an essential blue coloured acid dye, consisting of two azochromophore group widely used for studying the number of viable cells present in a population. This dye does not penetrate into the cell wall of live cells which are grown in culture.

Procedure: The cells were suspended in a known quantity of PBS and the cell count was adjusted to $1 \times 10^{6}$ cells $/ \mathrm{ml}$. The P. amarus leaf extract at various concentrations $(0-0.2 \mathrm{mg} / \mathrm{ml})$ were prepared from the stock solution (10 $\mathrm{mg} / \mathrm{ml})$ in phosphate buffer saline solution (PBS). The PBS solution was added to all the tubes containing plant extract and the final volume was made to $800 \mu \mathrm{l}$ with PBS. $100 \mu \mathrm{l}$ of HCT 15 and T47D cell lines in phosphate buffered saline was added to the tubes. A control having solvent alone was also prepared. They are then incubated at $37^{\circ} \mathrm{C}$ for 3 hours and $100 \mu \mathrm{l}$ of trypan blue was added to all test tubes. Cell counts were done using trypan blue dye exclusion method on haemocytometer by counting stained (non-viable) and unstained (viable) cells. Cell viability assay results were expressed as percentage of cell viability [24].

$$
\text { Calculation: } \quad \text { Viability percentage }=\frac{\text { live cell count }}{\text { total cell count }} \times 100
$$

2.4. Cytotoxic assay of cell lines by MTT assay- (4, 5-diMethyl Thiazol-2-yl) - 2, 5- diphenylTetrazolium bromide

MTT assay is based on the capacity of Mitochondrial succinate dehydrogenase enzyme in living cells to reduce the yellow water soluble substrate 3- (4, 5-dimethyl thiazol-2-yl)-2, 5 diphenyltetrazolium bromide (MTT) into an insoluble, purple blue colored formazan product which can be measured. Since reduction of MTT can only occur in metabolically active cells, the level of activity is a measure of the viability of the cells [25]. The trypsinized cells from T-25 flask were seeded in each well of 96-well flat bottom tissue culture plate at a density of $5 \times 10^{3}$ cells/well in growth medium and cultured at $37^{\circ} \mathrm{C}$ in $5 \% \mathrm{CO}_{2}$ adhere. After $48 \mathrm{hrs}$ incubation, the supernatant was discarded and the cells were pre-treated with growth medium and were subsequently mixed with different concentrations of leaf extract $(0-0.2 \mathrm{mg} / \mathrm{ml}) \mathrm{using}$ dimethylformamide solvent and then incubated for $48 \mathrm{hrs}$ at $37^{\circ} \mathrm{C}$ in $\mathrm{Co}_{2}$ incubator. The supernatant growth medium was removed by aspiration. Each well is then added with $5 \mu \mathrm{l}$ of fresh MTT $(0.5 \mathrm{mg} / \mathrm{ml}$ in PBS $)$ followed by incubation for $2 \mathrm{hr}$ at $37^{\circ} \mathrm{C}$ in dark. Formazan crystals formed after incubation were solubilised with $100 \mu \mathrm{l}$ of DMSO and incubated for $30 \mathrm{~min}$. The absorbance (OD) of the colored product in culture plate was read at a wavelength of 570nm on an ELISA reader (Thermo scientific multiscan, USA). Optical density is directly correlated with cell quantity. Culture medium along with DMSO without plant extract was used as control. The absorbance values which are lower than the control cells indicate a reduction in the rate of cell proliferation. Anticancer drug doxorubicin was used as a reference compound for determination of anticancer activity of cell lines. IC $_{50}$ values were calculated from the graph of percentage inhibition against sample concentration.

\section{Calculation:}

$\%$ Cell survival $=\left\{\left(A_{t}-A_{b}\right) /\left(A_{c}-A_{b}\right)\right\} \times 100$

Where,

$\mathrm{A}_{\mathrm{t}}=$ Absorbance value of test compound.

$\mathrm{A}_{\mathrm{b}}=$ Absorbance value of blank.

$\mathrm{A}_{\mathrm{c}}=$ Absorbance value of control.

$\%$ cell inhibition= 100 - cell survival.

\subsubsection{Statistical analysis}

The triplicate data were analyzed as mean \pm standard deviation. Data was statistically analyzed by Graph pad prism (ver. 7.0.1). 


\section{Results and discussion}

\subsection{Anti-cancer activity of dimethylformamide leaf extract of Phyllanthus amarus against HCT 15 and T47D cell lines}

The cytotoxic effect of plant extract was tested by the MTT assay, which showed the effect of its secondary metabolites on the cell viability in HCT 15 and T47D cancer cell lines. The percentage viability of the HCT 15 and T47D cancer cells were calculated before treating with various concentrations of plant extract. $97.87 \%$ of viability was shown by HCT 15 cell lines and $98.44 \%$ of viability was shown by T47D cell lines which are most suitable to perform MTT cytotoxicity studies (Table 2).

Table 2 Percentage of cell viability of cancer cell lines.

\begin{tabular}{|l|l|l|l|l|}
\hline Cell line & \% viability & Live cell count & Total cell count & pH \\
\hline T47D & $98.44 \%$ & $2.473 \times 10^{3}$ & $2.512 \times 10^{3}$ & 7.5 \\
HCT 15 & $97.87 \%$ & $2.528 \times 10^{3}$ & $2.583 \times 10^{3}$ & 6.9 \\
\hline
\end{tabular}

\subsection{Trypan blue staining}

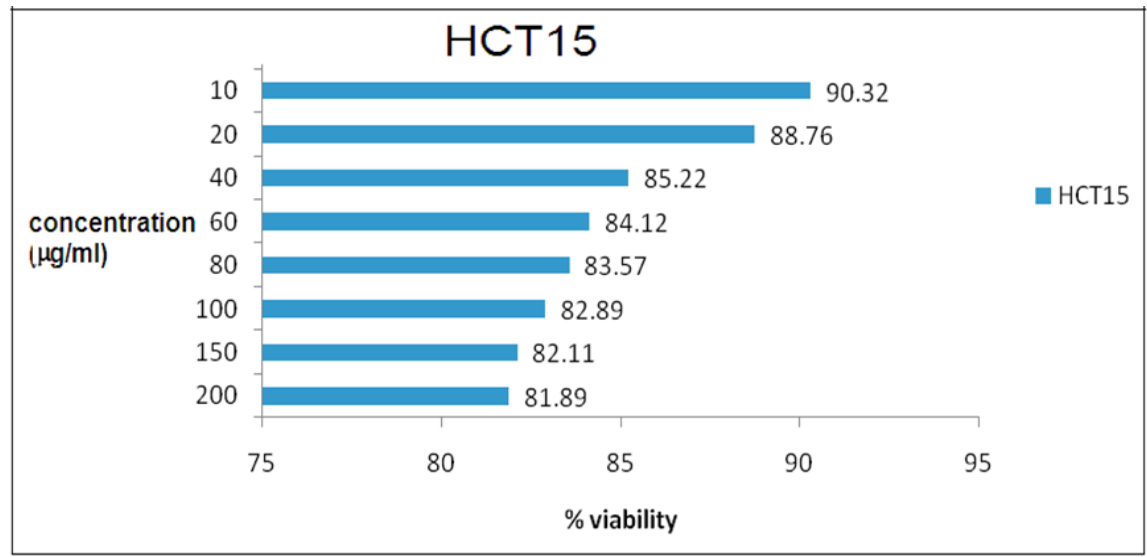

Figure 1 Effect of different concentrations of leaf extract of $P$. amarus on viability percentage of HCT15 cell lines

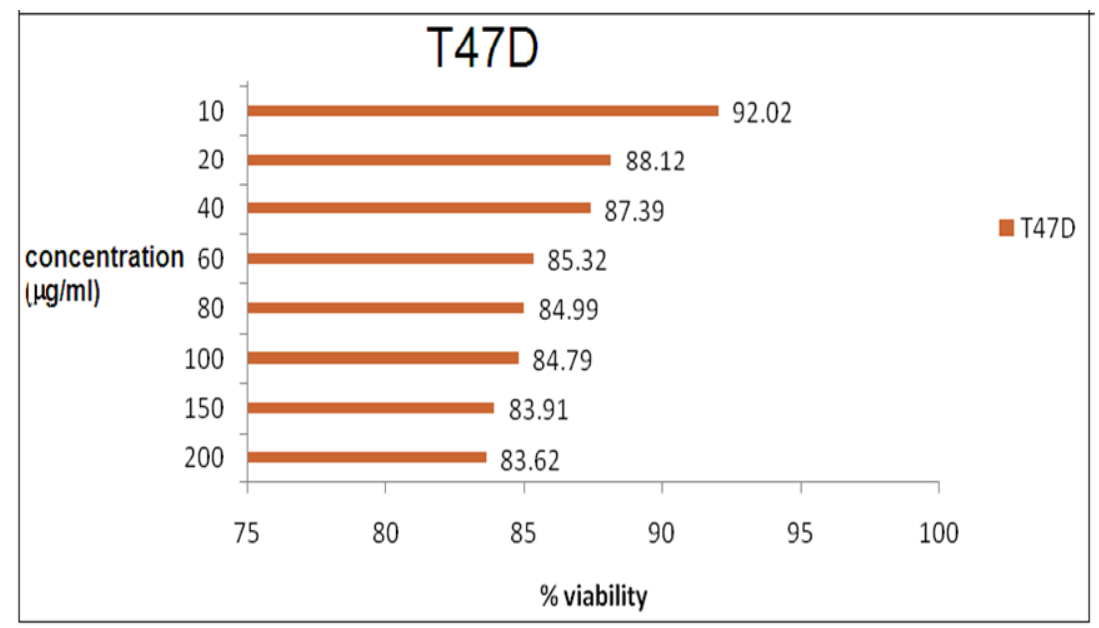

Figure 2 Effect of different concentrations of leaf extract of $P$. amarus on viability percentage of T47D cell lines

Percentage of cell viability of cell lines were carried out by Trypan blue staining using haemocytometer. After treating the cells with different concentrations of leaf extract $(0-0.2 \mathrm{mg} / \mathrm{ml})$, it was found that with the increasing concentration of leaf extract, the percentage viability of cancer cell lines was decreased (Fig.1,2). 


\subsection{MTT Assay results of Phyllanthus amarus dimethyl formamide leaf extract}

A plotted graph of anticancer activity of dimethylformamide leaf extract of $P$. amarus on HCT 15 and T47D cell lines using MTT assay was shown in Fig.5 and Fig.6 respectively. With the increasing concentration of dimethylformamide leaf extract from 10 to $200 \mu \mathrm{g} / \mathrm{ml}$, the HCT 15 cancer cell line growth inhibition increased from 8.86\% to 87.22 \% (Table 3, Fig.3) and the T47D cancer cell line growth inhibition increased from $8.39 \%$ to $86.01 \%$ (Table 4, Fig.4). This shows that the leaf extract inhibit the growth of the cancer cells and the inhibitory effect on HCT 15 cell line is comparatively greater than T47D cell line. The $\mathrm{IC}_{50}$ value was found to be $106.7 \mu \mathrm{g} / \mathrm{ml}$ for HCT 15 cancer cell line and $90.3 \mu \mathrm{g} / \mathrm{ml}$ for T47D cancer cell line, which shows that the anticancer activity of leaf of $P$. amarus is comparable to positive control drug doxorubicin and can be used as good anticancer agent.

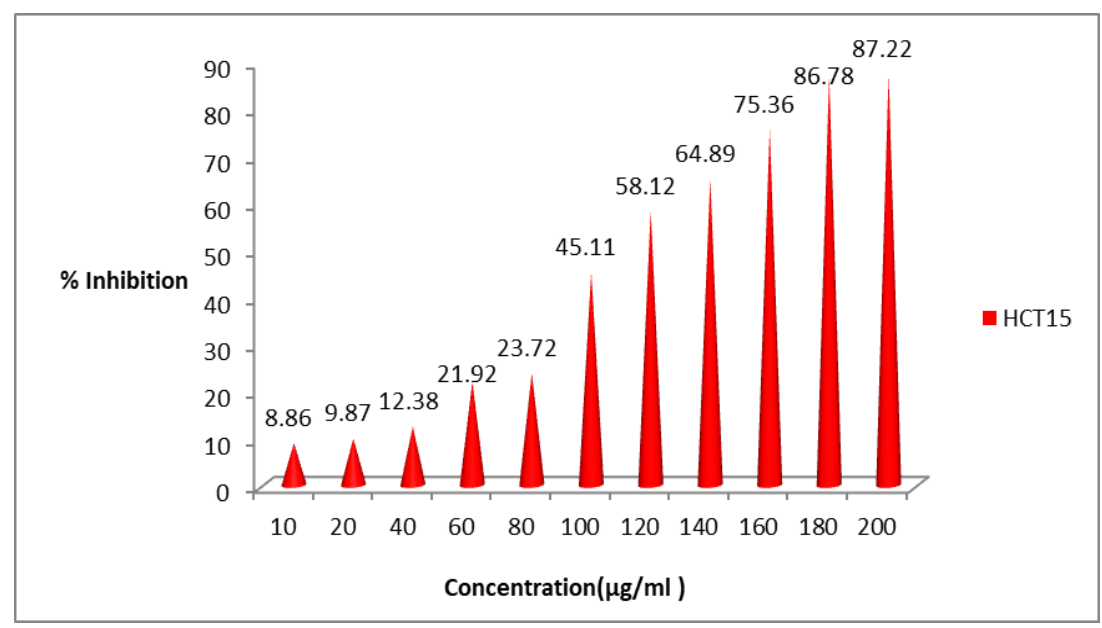

Figure 3 Cytotoxic activity of various concentrations of leaf extract of $P$. amarus against HCT15 cell line by MTT assay

Table 3 Inhibition percentage of HCT15 cell line at various concentrations of leaf extract by MTT assay.

\begin{tabular}{|c|c|c|c|}
\hline $\begin{array}{l}\text { Concentration } \\
\mu \mathrm{g} / \mathrm{ml}\end{array}$ & $\begin{array}{l}\% \text { of HCT } 15 \\
\text { cell inhibition }\end{array}$ & $\mathrm{IC}_{50}$ & $\mathbf{R}^{2}$ Value \\
\hline 200 & $87.22 \pm 0.75$ & \multirow{12}{*}{$106.7 \pm 0.62$} & \multirow{12}{*}{0.96} \\
\hline 180 & $86.78 \pm 0.64$ & & \\
\hline 160 & $75.36 \pm 0.49$ & & \\
\hline 140 & $64.89 \pm 0.77$ & & \\
\hline 120 & $58.12 \pm 0.58$ & & \\
\hline 100 & $45.11 \pm 0.83$ & & \\
\hline 80 & $23.72 \pm 0.66$ & & \\
\hline 60 & $21.92 \pm 0.52$ & & \\
\hline 40 & $12.38 \pm 0.69$ & & \\
\hline 20 & $9.87 \pm 0.65$ & & \\
\hline 10 & $8.86 \pm 0.52$ & & \\
\hline & $22.88 \pm 0.53$ & & \\
\hline
\end{tabular}




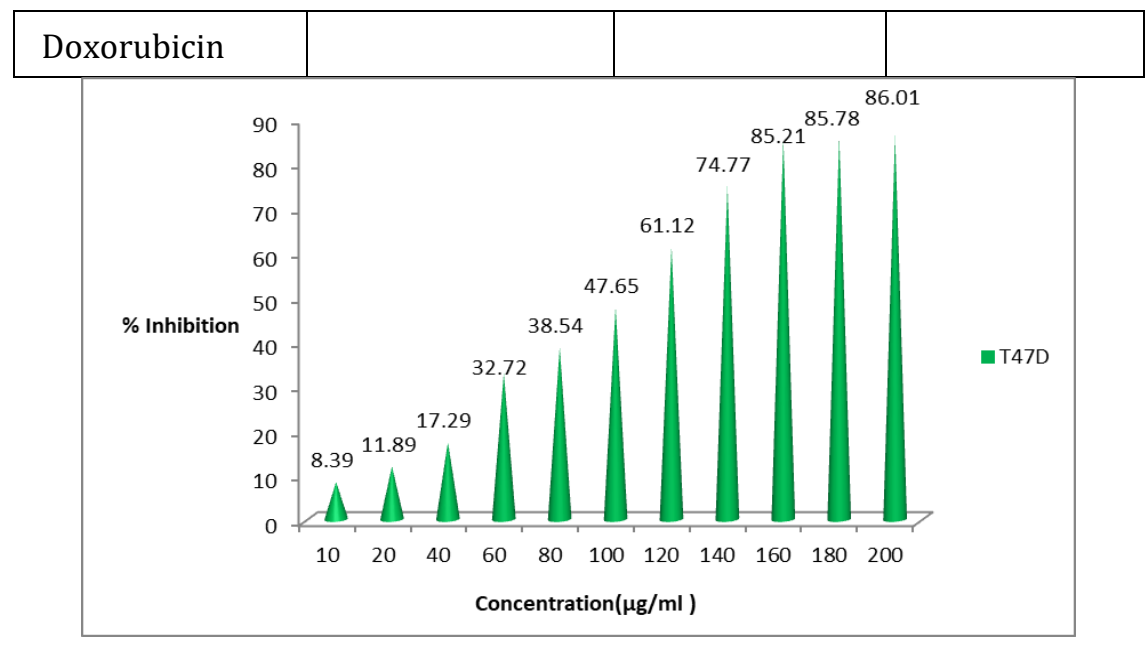

Figure 4 Cytotoxic activity of various concentrations of leaf extract of $P$. amarus against T47D cell line by MTT assay

Table 4 Inhibition percentage of T47D cell line at various concentrations of leaf extract by MTT assay

\begin{tabular}{|c|c|c|c|}
\hline $\begin{array}{l}\text { Concentration } \\
\mu \mathrm{g} / \mathrm{ml}\end{array}$ & $\begin{array}{l}\text { \% of T47D } \\
\text { inhibition }\end{array}$ & $\mathrm{IC}_{50}$ & $\mathbf{R}^{2}$ Value \\
\hline 200 & $86.01 \pm 0.53$ & \multirow{12}{*}{$90.3 \pm 0.57$} & \multirow{12}{*}{0.963} \\
\hline 180 & $85.78 \pm 0.62$ & & \\
\hline 160 & $85.21 \pm 0.49$ & & \\
\hline 140 & $74.77 \pm 0.66$ & & \\
\hline 120 & $61.12 \pm 0.71$ & & \\
\hline 100 & $47.65 \pm 0.43$ & & \\
\hline 80 & $38.54 \pm 0.58$ & & \\
\hline 60 & $32.72 \pm 0.68$ & & \\
\hline 40 & $17.29 \pm 0.70$ & & \\
\hline 20 & $11.89 \pm 0.56$ & & \\
\hline 10 & $8.39 \pm 0.60$ & & \\
\hline Doxorubicin & $46.87 \pm 0.53$ & & \\
\hline
\end{tabular}

MTT Assay of DMF leaf extract of $P$. amarus against HCT 15 Cell line

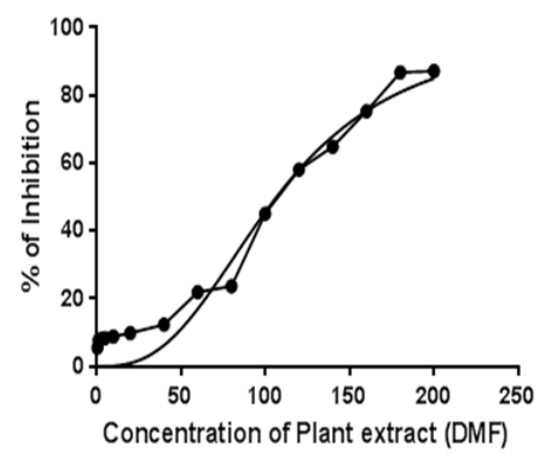


Figure 5 Anticancer activity of dimethylformamide leaf extract of $P$. amarus on HCT 15 cell line using MTT assay

\section{MTT Assay of DMF leaf extract of $P$. amarus against T47D Cell line}

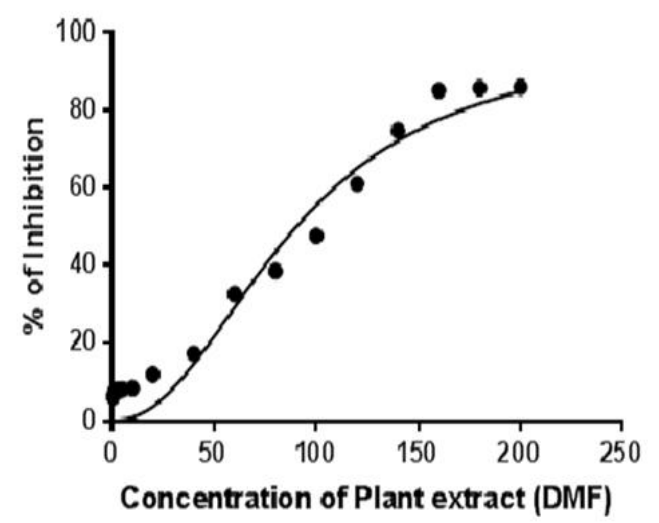

Figure 6 Anticancer activity of dimethylformamide leaf extract of P. amarus on T47D cell line using MTT assay

In a previous report, the compounds n-Hexadecanoic acid, N-Methoxy-N-methyl acetamide, Ursa-9 (11), 12-dien-3-ol, gammasitosterol were found to be responsible for biological activity [26]. There is no report in literature regarding testing the cytotoxic potential of dimethylformamide leaf extract of $P$. amarus against Human colorectal adeno carcinoma (HCT 15) and Human breast cancer (T47D) cell lines by MTT assay. n-hexane and chloroform extracts of heart wood of Albizia adianthifolia[27] and ethanolic extract of whole plant of Aristolochia krysagathra[28] were reported to have trans-13-octadecanoicacid and 9,12-Octadecadienoic acid compounds respectively, which belong to methyl ester group and display anti-cancer properties. The presence of a diterpene compound called 2-Cyclopenten-1one, 2-hydroxy in ethanolic leaf extract of Bruguiera cylindrica showing antimicrobial and anticancer properties have been reported [29]. They also reported phenolic compounds possessing antimicrobial, antioxidant and anticancer properties. Whole plant extracts of Calanthe triplicate in ethyl acetate extracts revealed the presence of $4 \mathrm{H}-\mathrm{Pyran}-4$ one, 2,3-dihydro-3,5- dihydroxy-6-methyl which is a flavonoid compound exhibiting antimicrobial, anticancer and antiinflammatory properties [30]. Phytol, which is a diterpene compound, is reported to have antioxidant, antiinflammatory and anticancer properties in ethanolic leaf extract of Cyperus rotundus [31]. Antioxidant, antiinflammatory and anticancer properties in methanolic leaf extract of Eupatorium triplinerve have been reported [32]. An Isoprenoid compound named Squalene showing antioxidant and anticancer properties and a ketone compound named 3, 7, 11, 15-Tetramethyl-2-hexadecen-1-ol exhibiting anti-inflammatory and anti-cancer properties were reported in methanolic leaf extract of Eupatorium triplinerve [32]. These extracts also have 2, 6, 10-trimethyl, 14ethylene-14-pentadecane, which exhibit anti-fungal, antibacterial and anti-cancer properties and 5-Hydroxymethyl furfural which exhibits anti-oxidant and anti-cancer properties. Tetradecanoic acid, which is a Myristic acid, is found to have antioxidant and anticancer properties in ethanol extract of bark of Hugonia mystax [33]. Tetradecanoic acid, which is a Myristic acid, is found to have antioxidant and anticancer properties in ethanolic leaf extracts of Hyptis lanceolata Poir. [34]. Steroid compounds 7-dehydrodiosgenin and lupeol were also found to have anticancer properties in $n$ hexane and chloroform extracts of stem bark of Pterocarpus angolensis [27]. An ester, 10 Dotriacontylpentafluoropropionate is found to have cytotoxic properties in wild and mutant strains of Schizophyllum commune [35]. All the above reports show that various esters, acids, phenols, flavonoids, isoprenoids, ketones, hydrocarbons, steroids compounds present in plants are responsible for various types of activities. All the above reports confirm that esters, acids, and flavonoid compounds which occur in P. amarus were the major cause for its anti-cancer activity and other medicinal properties.

\section{Conclusion}

These findings report Phyllanthus amarus as a potential plant exhibiting anticancer properties. Scientific study of the plant for its chemical constituents helps in understanding of their functional properties for development and designing of effective anticancer drugs. Safe and effective use of this plant in prevention of cancer helps to recommend it as a 
dietary supplement. The mechanism of action against cancer cell proliferation and the regulation of apoptotic pathway are yet to be investigated using preliminary in vitro data for removing the barriers towards in vivo applications.

\section{Compliance with ethical standards}

\section{Acknowledgments}

We thank Centre for Biotechnology, Institute of Science and Technology, Jawaharlal Nehru Technological University Hyderabad, Kukatpally, Hyderabad for providing infrastructural facilities.

\section{Disclosure of conflict of interest}

The authors declare that they have no conflict of interest.

\section{References}

[1] Ames BN, Gold LS, Willet WC. The causes and prevention of cancer. Proc. Natl. Acad. Sci. 1995; 92(12): 52585265.

[2] Kutluk K, Kars A. General Knowledge about cancer, Ankara.Turkey cancer investigation and fight society publications. 1998; 7-15.

[3] Cragg GM, Newman DJ. Plants as a source of anti-cancer agents. Journal of Ethnopharmacology. 2005; 100(12):72-79.

[4] Ferlay J, Soerjomataram I, Dikshit R, Eser S, Mathers C, Rebelo M, Parkin DM, Forman D, Bray F. Cancer incidence and mortality worldwide: sources, methods and major patterns in GLOBOCAN 2012. International Journal of Cancer. 2015; 136(5):E359-386.

[5] Kaur R, Karan Kapoor, Harpreet Kaur. Plants as a source of anticancer agents. The Journal of Natural Product and Plant Resources. 2011; 1(1): 119-124.

[6] Muruganantham N, Solomon S, Senthamiselvi MM. Anti-cancer Activity of Cucumis sativus (Cucumber) Flowers Against Human Liver Cancer. International Journal of Pharmaceutical and Clinical Research. 2016; 8(1):39-41.

[7] Gali-Muhtasib H, Hmadi R, Kareh M, Tohme R, Darwiche N. Cell death mechanisms of plant-derived anticancer drugs: beyond apoptosis. Apoptosis, International Journal on Programmed Cell Death. 2015; 20(12):1531-1562.

[8] Murugaiyah V. Phytochemical, pharmacological and pharmacokinetic studies of Phyllanthus niruri Linn. Lignans as potential anti-hyperuricemic agents. University Sains Malaysia. 2008.

[9] Patel JR, Tripathi P, Sharma V, Chauhan NS, Dixit VK. Phyllanthus amarus : Ethnomedicinal uses, phytochemistry and pharmacology: A review. Journal of Ethnopharmacology. 2011; 138(2): 286-313.

[10] Sravanthi PSS, Padmavathi TVS, Archana Giri. Metabolic fingerprinting of root, stem and leaf extracts of Phyllanthus amarus. Journal of Phytology. 2016; 8: 17-21.

[11] Alli AI, Ehinmidu JO, Ibrahim YKE. Preliminary phytochemical screening and antimicrobial activities of some medicinal plants used in Ebiraland. Bayero Journal of Pure and Applied Sciences. 2011; 4(1): 10-16.

[12] Sravanthi PSS, Padmavathi TVS, Archana Giri. Anti-microbial activity of Phyllanthus amarus plant extracts using polar and non-polar solvents against gram positive and gram negative bacteria. International Journal of Current Research. 2015; 7(12):24687-24692.

[13] Akporowhe S, Onyesom I. Phyllanthus amarus augments the serum antioxidant capacity and invigorates the blood in experimental mice. Bioscience biotechnology research communications. 2016; 9(1): 15-18.

[14] Sravanthi PSS, Padmavathi TVS, Archana Giri. Evaluation of Anti-oxidant potential of root, stem and leaf extracts of Phyllanthus amarus. International Journal of Advanced Research in Science and Technology. 2016; 5(3): 653661.

[15] Suh DK, Lee EJ, Kim HC, Kim JH. Induction of G1/S phase arrest and apoptosis by quercetin in human osteosarcoma cell. Archives of Pharmacal Research. 2010; 33(5): 781-785. 
[16] Agarwal C, Tyagi A, Agarwal R. Gallic acid causes inactivating phosphorylation of cdc25A/cdc25C-cdc2 via ATMChk2 activation, leading to cell cycle arrest, and induces apoptosis in human prostate carcinoma DU145 cells. Mol Cancer Ther. 2006; 5(12): 3294-3302.

[17] Saranraj P,Sivasakthivelan P. Screening of antibacterial activity of the medicinal plant Phyllanthus amarus against urinary tract infection causing bacterial pathogens. Applied Journal of Hygiene. 2012; 1(3): 19-24.

[18] Tang YQ, SekaranSD. Evaluation of Phyllanthus for its anti-Cancer properties, prostate Cancer - From Bench to Bedside, Dr. Philippe E. Spiess (Ed.), ISBN: 978-953-307-331-6, In Tech. 2011.

[19] Rindsjo E. Mechanisms of action of anti-cancer drugs, Karolinska institute, Department of Oncology. 2015.

[20] Payne S, Miles D (2008). Mechanisms of anticancer drugs. Cell biology, Chapter 4, 2008; 34-46.

[21] Tang YQ Jaganath IB, Sekaran SD. Phyllanthus spp. induces selective growth inhibition of PC-3 and MeWo human cancer cells through modulation of cell cycle and induction of apoptosis. Plos one. 2010; 5(9): e12644.

[22] Tang YQ, Jaganath IB, Manikam R, Sekaran SD. Anti-Metastatic effects through Inhibition on Matrix Metalloproteinase Enzymes. Nutrition and Cancer. 2015; 67(5): 783-795.

[23] Huang ST, Wang CY, Yang RC, Wu HT, Yang SH, Cheng YC, Pang JH. Ellagic Acid, the active compound of Phyllanthus urinaria, exerts in vivo anti-angiogenic effect and inhibits MMP-2 activity. Evidence-Based Complementary And Alternative Medicine. 2011:215035.

[24] Saluja MS, Sangameswaran B, Hura IS, Ajay Sharma, Gupta SK, Chaturvedi M. In-vitro cytotoxic activity of leaves of Madhuca longifolia against Ehrlich Ascites carcinoma (EAC) cell lines. International Journal of Drug Discovery and Herbal Research. 2011; 1(2): 55-57.

[25] Mosmann T. Rapid colorimetric assay for cellular growth and survival: application to proliferation and cytotoxicity assays. The Journal of Immunological Methods. 1983; 65(1-2): 55-63.

[26] Anjaneyulu Musini, Jayaram Prakash Rao, ArchanaGiri. Phytochemicals of Salacia oblonga responsible for free radical scavenging and antiproliferative activity against breast cancer cell lines (MDA-MB-231). Physiology and Molecular Biology of Plants. 2015; 21(4):583-590.

[27] Abubakar MN, Majinda Runner RT. GC-MS Analysis and Preliminary Antimicrobial Activity of Albizia adianthifolia (Schumach) and Pterocarpus angolensis (DC). Medicines. 2016; 3(3):1-9.

[28] Jegadeeswari P, Nishanthini A, Muthuasamya S, Mohan VR. GC-MS analysis of bioactive components of Aristolochia krysagathra (Aristolochiaceae). Journal of Chemical and Pharmaceutical Sciences. 2012; 2(4):226232.

[29] Revathi P, Jeyaseelansenthinath T,Thirumalaikolundhusubramaian P. Preliminary phytochemical screening and GC-MS analysis of ethanolic extract of mangrove Plant-Bruguiera cylindrica (Rhizho) L. International Journal of Pharmacognosy and Phytochemical Research. 2015; 6(4): 729-740.

[30] Mythili K, Reddy CU, Chamundeeswari D, Manna PK. GC-MS analysis of phytocomponents and in-vitro inhibitory effects of Calanthe triplicate. Journal of Natural Products. 2013; 6:141-146.

[31] Elezabeth VD, Arumugam S. GC - MS analysis of ethanol extract of Cyperus rotundus leaves. International Journal of Current Biotechnology. 2014; 2(1):19-23.

[32] Sugumar N,Karthikeyan S. Preliminary Phytochemical Screening GC-MS and FTIR profiling of methanolic extract of leaves on Eupatorium triplinerve Vahl. International Journal of Multidisciplinary Research and Development. 2015; 2(8): 335-340.

[33] Rajeswari G, Murugan M, Mohan VR. GC-MS analysis of bioactive components of Hugonia mystax L. barks (Linaceae). Journal of Pharmaceutical and Biomedical Sciences. 2013; 29(29):818-824.

[34] Igwe OU. Chromatographic and spectrometric characterization of bioactive compounds from the Leaves of Hyptis lanceolata Poir. International Journal of Chemistry and Pharmaceutical Sciences. 2014; 2(1): 547-553.

[35] Aina DA, Oloke JK, Awoyinka OA, Adebayo EA, Akoni OI, Agbolade JO,Odeniyi KM. Comparative cytotoxic effect of metabolites from wild and mutant strains of Schizophyllum commune grown in submerged liquid medium. American Journal of Research Communication. 2013; 1(7): 219-240. 